\title{
Biochemical Composition of Seven Species of Cyanobacteria Isolated from Different Aquatic Habitats of Western Ghats, Southern India
}

\author{
Karanth Rama Rajeshwari* and Madaiah Rajashekhar \\ Department of Biosciences; Mangalore University; Mangalagangotri, 574199, Karnataka - India
}

\begin{abstract}
The aim of this work was to study the biochemical constituents of seven species of cyanobacteria namely, Calothrix fusca, Gloeocapsa livida, Lyngbya limnetica and Scytonema bohneri isolated from Panekal sulfur spring. The species namely, Oscillatoria acuminata from petrochemical refinery, O. calcuttensis from dairy effluent and $\mathrm{O}$. foreaui from a sewage drain located in the Western Ghats of Southern India under laboratory culture conditions. The biochemical constituents were analyzed in terms of total carbohydrates, total protein, total free amino acid, total lipid, fatty acid and mineral contents. The analysis showed that maximum amount of total carbohydrate in S. bohneri (28.4\% dry weight) and minimum in O. foreaui (8.0\% of dry weight). Maximum amount of total protein and total free amino acid were in O. foreaui (7\% of dry weight). O. calcuttensis showed higher amount of total lipid (20\% dry weight). A total of 12 types of fatty acids were detected among which lauric acid was in highest quantity in all the seven species. Among the polyunsaturated fatty acids, oleic acid was present in all the species ranging from 1.68 to $3.89 \%$. O. foreaui showed highest quantities of copper, manganese, ferrous and zinc. Nickel was maximum in $\mathrm{S}$. bohneri $\left(11.05 \mu \mathrm{gmL}^{-1}\right)$. O. acuminata showed highest quantity of magnesium $\left(21.050 \mathrm{mg} \mathrm{g}^{-1}\right)$ and it was least in O. foreaui (12.812 $\left.\mathrm{mg} \mathrm{g}^{-1}\right)$.
\end{abstract}

Key words: cyanobacteria, polluted waters, sulfur spring, biochemical constituents

\section{INTRODUCTION}

Cyanobacteria are one of the useful organisms widely used in food industries and in few biotechnological applications (Venkataraman and Becker, 1985; Fatma et al., 1994; Thajuddin and Subramanian, 2005; Rastogi and Sinha, 2009). They store reserve food materials which can be used as the source of pigments, lipids, vitamins, proteins and certain secondary metabolites (Tan,
2007; Cardozo et al., 2007). Cyanobacterial protein has received worldwide attention for either as food supplement or as an alternative source of food. Some species of Anabaena, Nostoc and Spirulina are consumed as food due to their high protein and fibre content (Anusuya et al., 1981; Anupama, 2000). A large number of marine nitrogen fixing cyanobacteria serve as complete aquaculture feed source due to their nutritional quality and non toxic property. They are also rich

*Author for correspondence: rajeeholla@yahoo.co.in 
in vitamins and amino acids (Ciferri and Tiboni, 1985; Borowitzka, 1988). They contain significant quantity of lipids and fatty acids. Mahajan and Kamat (1995) reported that Spirulina platensis accumulated large amount of gamma linolenic acid. Fatty acid profile is used as an effective taxonomic tool for many species (Kruger et al., 1995; Li and Watanabe, 2004). In addition, minerals like zinc, magnesium and selenium are reported in some species (Jensen and Ginsberg, 2000). Due to their ability to accumulate heavy metals either by bioaccumulation or biosorption, cyanobacteria are useful for heavy metal removal from the polluted waters (Karna et al., 1999).

At present, effort is made on large-scale production of their metabolites for therapeutic use by culturing them under controlled laboratory conditions. In this work, the total carbohydrates, total proteins, total amino acids, total lipids, fatty acid profile and mineral content in the seven species isolated from the study area located at Western Ghats of Karnataka, Southern India were studied.

\section{MATERIALS AND METHODS}

\section{Sampling locations}

Cyanobacterial samples were collected in the Western Ghats region of Dakshina Kannada district of Karnataka, Southern India in three consecutive seasons $(2003-04,2004-05$, and 2005- 06). The samples were taken from the following areas: four species of cyanobacteria namely, Calothrix fusca, Gloeocapsa livida, Lyngbya limnetica and Scytonema bohneri were isolated from Panekal sulfur spring; Oscillatoria acuminata was isolated from petrochemical effluents; Oscillatoria calcuttensis from dairy effluents and $O$. foreaui from sewage water of a municipal drain situated at the outskirts of Mangalore city.

\section{Isolation of cyanobacteria}

Water samples were collected in five liter plastic cans. The method of isolation and purification of cyanobacteria were according to Ferris and Hirsch (1991). A sample was shaken to suspend the sediment and then triplicate aliquots were removed and diluted with $100 \mathrm{ml}$ of sterile distilled water and was filtered using Millipore filters. The filters were placed onto the Petri plates containing BG-11 medium (Stanier et al., 1971). The plates were incubated for 15 days and were microscopically examined for the growth of cultures. Individual species were picked aseptically, sub-cultured in $500 \mathrm{~mL}$ Erlenmeyer flasks and incubated under continuous illumination (2000 lux) at $28 \pm 2^{\circ} \mathrm{C}$ with 14:10 h light: dark regime. The BG-11 medium without combined nitrogen source was used for the isolation and maintenance of Calothrix fusca and Scytonema bohneri. After 30 days, the cultures were harvested for the analysis of biochemical constituents.

\section{Biochemical analysis \\ Total carbohydrate}

For total carbohydrate, $100 \mathrm{mg}$ of dried, preweighed cyanobacterial sample was hydrolyzed with $2.5 \mathrm{~N}$ hydrochloric acid at $100^{\circ} \mathrm{C}$ for one hour to prepare the extract. The total carbohydrate was determined according to Dubois et al. (1956). For this, $0.2 \mathrm{ml}$ sample of the extract was transferred to an assay tube to which $1.0 \mathrm{ml}$ of $5 \%$ phenol and $5.0 \mathrm{~mL}$ of concentrated sulphuric acid was added, with the tubes placed in water bath maintained at $25^{\circ} \mathrm{C}$ for 30 minutes. The samples were then analysed at $490 \mathrm{~nm}$ using UV - visible spectrophotometer (Systronics India Ltd.) against the blank and compared with the standard glucose solution (concentration from 10 to $100 \mu \mathrm{g} \mathrm{mL}^{-1}$ ).

\section{Total protein}

The total protein was determined according to Lowry's method (Lowry et al., 1951). The cyanobacterial proteins were precipitated by hot $6 \%$ trichloro acetic acid, extracted with $4.5 \mathrm{ml}$ hot $\left(55^{\circ} \mathrm{C}\right)$ alkaline reagent (i.e., $2 \%$ alkaline $\mathrm{Na}_{2} \mathrm{CO}_{3}$ and $\mathrm{CuSO}_{4}-\mathrm{Na}-\mathrm{K}$ tartarate solution) for $3 \mathrm{~min}$; the filtrate was collected and the volume was made up to $5.0 \mathrm{ml}$ with alkaline reagent. About $0.5 \mathrm{ml}$ of Folin-Ciocalteau was added and mixed rapidly and allowed to stand for $10 \mathrm{~min}$. at room temperature. After the color development, spectrophotometric readings at $750 \mathrm{~nm}$ were determined and compared with the results from solutions of bovine serum albumin standards in concentration from 40 to 200 $\mu \mathrm{g} \mathrm{mL} \mathrm{m}^{-1}$.

\section{Total free amino acid}

For amino acid analysis, $50 \mathrm{mg}$ of the dried sample and $10 \mathrm{~mL}$ of $80 \%$ ethanol were used to prepare an extract. Total free amino acid content was estimated by Moore and Stein's ninhydrin reaction (Moore and Stein, 1948). For this, $1.0 \mathrm{ml}$ of extract was transferred to the assay tube. Then, 
$3.8 \mathrm{~mL}$ of Ninhydrin reagent was added and tubes were heated in a boiling water bath for $12 \mathrm{~min}$.. The samples were then analysed at $570 \mathrm{~nm}$ using UV - visible spectrophotometer (Systronics India Ltd.) against the blank and compared with the standard leucine solution which ranged between 10 and $100 \mu \mathrm{gL}^{-1}$.

\section{Total lipid and fatty acid}

Total lipid content was evaluated using Folch's method (Folch et al., 1957) and fatty acids were determined by gas chromatography (Miller and Berger, 1985). The total lipids of the dried samples (about $100 \mathrm{mg}$ ) were extracted with chloroform methanol solvent $(2: 1, \mathrm{v} / \mathrm{v})$ and the filtrate was transferred to a pre-weighed bottle. It was dried in an evaporator and final weight was taken. The difference between the initial weight and final weight gave the total lipid content. The total lipids were dissolved in $1.0 \mathrm{ml}$ of chloroform - methanol $(2: 1, v / v)$ for the analysis of fatty acids. Fatty acids were determined by gas chromatographic technique (Miller and Berger, 1985).

\section{Analysis of mineral content}

For the analysis of metallic elements, $0.5 \mathrm{~g}$ of the dried cyanobacterial mass and $5.0 \mathrm{ml}$ of $1.0 \mathrm{~N}$ nitric acid were used to prepare an extract. The mineral concentrations of the sample extract were determined by atomic absorption spectrophotometry (GBC AVANTA, Germany) as described by Poppiti and Sellers (1994).

\section{Statistics}

The results are expressed as the mean $\pm \mathrm{SD}$ of three experiments.

\section{RESULTS}

The cellular constituents of the selected species of cyanobacteria expressed in percentage dry weight are given in Fig.1. These were 19.5, 18.0, 18.4 and $28.4 \%$ for C. fusca, G. livida, L limnetica and $S$. bohneri respectively; the percentage of total protein were 1.6, 1.8, 3.1 and $0.7 \%$ respectively; the total free amino acid content were between 1.7 $-5.3 \%$ and the total lipids were between 10.5 and $14.5 \%$. Of the three species of Oscillatoria isolated from different effluent waters, $O$. acuminata showed $14.0 \%$ of total carbohydrate and total lipids; O. foreaui showed $8.0 \%$ of total carbohydrate and total lipids. The total protein was $6.9 \%$ and total amino acid content was $1.8 \%$ and $7 \%$, respectively, of Oscillatoria acuminata and $O$. foreaui. $O$. calcuttensis isolated from dairy effluents showed 9.6, 2.2, 20.0 and $2.1 \%$ of total carbohydrate, total protein, total lipids and total free amino acids, respectively.

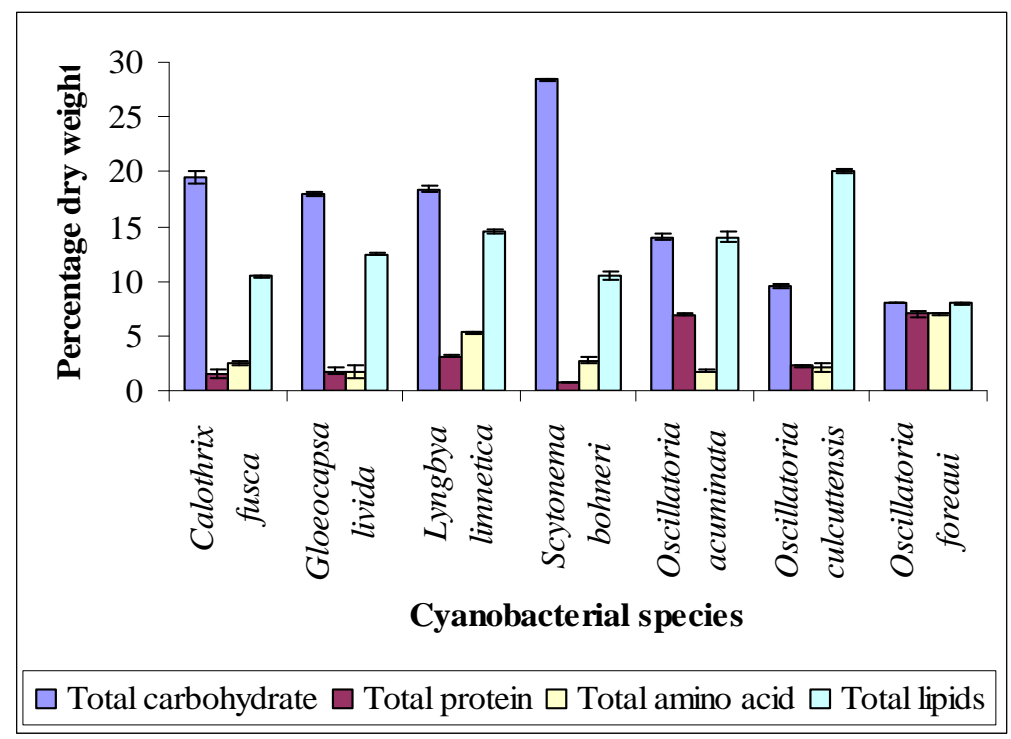

Figure 1 - Cellular constituents of cyanobacterial species isolated from different aquatic habitats expressed in \% of dry weight. Bars indicate the standard deviation. 
The fatty acid profile is presented in Table 1 . Of the 13 different fatty acids analyzed, a total of 12 types of fatty acids were detected. These species appeared to synthesize seven types of saturated fatty acids $\left(\mathrm{C}_{8: 0}, \mathrm{C}_{10: 0}, \mathrm{C}_{12: 0}, \mathrm{C}_{14: 0}, \mathrm{C}_{16: 0}, \mathrm{C}_{18: 0}\right.$ and $\mathrm{C}_{20: 0}$ ) and five types of polyunsaturated fatty acids (PUFA) $\left(\mathrm{C}_{16: 1}, \mathrm{C}_{18: 1}, \mathrm{C}_{18: 2}, \mathrm{C}_{18: 3}\right.$, and $\left.\mathrm{C}_{22: 1}\right)$ of which lauric acid $\left(\mathrm{C}_{12: 0}\right)$ was present in the highest quantities in all the seven species. G. livida and $O$. foreaui showed high lauric acid content, i.e., 45.3 and $44.53 \%$, respectively. The other predominant fatty acid recorded was myristic acid $\left(\mathrm{C}_{14: 0}\right)$. The arachidic acid $\left(\mathrm{C}_{20: 0}\right)$ and erucic acid $\left(\mathrm{C}_{22: 1}\right)$ were present only in L. limnetica $(0.25$ and $0.33 \%$, respectively). Caprylic acid $\left(\mathrm{C}_{8: 0}\right)$ and capric acid $\left(\mathrm{C}_{10: 0}\right)$ content was maximum in $C$. fusca but minimum in L limnetica. Of the polyunsaturated fatty acids, oleic acid $\left(\mathrm{C}_{18: 1}\right)$ was present in all the species that ranged between 1.68 and $3.89 \%$. However, linoleic acid $\left(\mathrm{C}_{18: 2}\right)$ was detected in all the species, except $S$. bohneri and G. livida. But linolenic acid $\left(\mathrm{C}_{18: 3}\right)$ was present only in $O$. foreaui isolated from sewage with $2.28 \%$.

Table 1 - Fatty acid composition* (in \%) of seven species of cyanobacteria isolated from different aquatic habitats of the Western Ghats, Karnataka.

\begin{tabular}{|c|c|c|c|c|c|c|c|}
\hline \multirow{2}{*}{$\begin{array}{l}\text { Fatty acid } \\
\text { profile }\end{array}$} & \multicolumn{4}{|c|}{ Sulfur spring water } & \multirow{2}{*}{$\begin{array}{c}\begin{array}{c}\text { Petrochemical } \\
\text { effluent }\end{array} \\
\text { Oscillatoria } \\
\text { calcuttensis }\end{array}$} & \multirow{2}{*}{$\begin{array}{c}\text { Sewage water } \\
\text { Oscillatoria } \\
\text { acuminata }\end{array}$} & \multirow{2}{*}{$\begin{array}{c}\text { Dairy effluen } \\
\text { Oscillatoria } \\
\text { foreaui }\end{array}$} \\
\hline & $\begin{array}{l}\text { Lyngbya } \\
\text { limnetica }\end{array}$ & $\begin{array}{l}\text { Calothrix } \\
\text { fusca }\end{array}$ & $\begin{array}{c}\text { Scytonema } \\
\text { bonheri }\end{array}$ & $\begin{array}{c}\text { Gloeocapsa } \\
\text { livida } \\
\end{array}$ & & & \\
\hline $\mathrm{C}_{8: 0}$ & & & & & & & \\
\hline $\begin{array}{l}\text { Caprylic acid } \\
\mathrm{C}_{10: 0}\end{array}$ & $3.36 \pm 0.7$ & $10.45 \pm 1.2$ & $9.58 \pm 0.5$ & $8.10 \pm 0.1$ & $8.13 \pm 2.3$ & $7.59 \pm 0.8$ & $7.45 \pm 0.3$ \\
\hline $\begin{array}{l}\text { Capric acid } \\
\mathrm{C}_{12: 0}\end{array}$ & $1.99 \pm 1.2$ & $6.85 \pm 0.6$ & $5.99 \pm 0.3$ & $5.86 \pm 0.5$ & $5.11 \pm 0.5$ & $4.66 \pm 1.9$ & $5.79 \pm 0.6$ \\
\hline $\begin{array}{l}\text { Lauric acid } \\
\mathrm{C}_{14: 0}\end{array}$ & $17.17 \pm 0.9$ & $41.39 \pm 0.2$ & $41.40 \pm 0.4$ & $45.30 \pm 0.6$ & $35.29 \pm 0.3$ & $33.33 \pm 0.3$ & $44.53 \pm 0.6$ \\
\hline $\begin{array}{l}\text { Myristic acid } \\
\mathrm{C}_{16: 0}\end{array}$ & $5.32 \pm 2.1$ & $11.92 \pm 0.4$ & $10.78 \pm 0.7$ & $16.77 \pm 0.9$ & $10.42 \pm 1.2$ & $10.58 \pm 0.7$ & $10.65 \pm 0.8$ \\
\hline $\begin{array}{l}\text { Palmitic acid } \\
\mathrm{C}_{16: 1}\end{array}$ & $6.09 \pm 0.2$ & $10.04 \pm 1.3$ & $8.33 \pm 0.3$ & $4.69 \pm 2.0$ & $7.46 \pm 0.5$ & $8.35 \pm 0.2$ & $7.17 \pm 1.1$ \\
\hline $\begin{array}{l}\text { Palmitoleic acid } \\
\mathrm{C}_{18: 0}\end{array}$ & $2.48 \pm 0.5$ & Nil & Nil & Nil & $0.27 \pm 1.5$ & Nil & Nil \\
\hline $\begin{array}{l}\text { Stearic acid } \\
\mathrm{C}_{18: 1}\end{array}$ & $1.60 \pm 1.5$ & $1.65 \pm 0.8$ & $1.88 \pm 0.5$ & Nil & $1.64 \pm 1.7$ & Nil & $1.66 \pm 0.5$ \\
\hline $\begin{array}{l}\text { Oleic acid } \\
\mathrm{C}_{18: 2}\end{array}$ & $3.10 \pm 1.1$ & $2.47 \pm 0.7$ & $2.09 \pm 1.9$ & $2.91 \pm 1.0$ & $3.72 \pm 0.7$ & $3.89 \pm 2.2$ & $1.68 \pm 2.3$ \\
\hline $\begin{array}{l}\text { Linoleic acid } \\
\mathrm{C}_{18: 3}\end{array}$ & $1.56 \pm 0.5$ & $1.14 \pm 0.4$ & Nil & Nil & $2.18 \pm 0.3$ & $2.94 \pm 1.4$ & $1.98 \pm 1.5$ \\
\hline $\begin{array}{l}\text { Linolenic acid } \\
\mathrm{C}_{20: 0}\end{array}$ & Nil & Nil & Nil & Nil & Nil & Nil & $2.28 \pm 0.6$ \\
\hline $\begin{array}{l}\text { Arachidic acid } \\
\mathrm{C}_{22: 1}\end{array}$ & $0.25 \pm 0.1$ & Nil & Nil & Nil & Nil & Nil & Nil \\
\hline $\begin{array}{l}\text { Erucic acid } \\
\mathrm{C}_{24: 0}\end{array}$ & $0.33 \pm 0.4$ & Nil & Nil & Nil & Nil & Nil & Nil \\
\hline Lignoceric acid & Nil & Nil & Nil & Nil & Nil & Nil & Nil \\
\hline
\end{tabular}

${ }^{*}$ Values are the means of three replicates \pm standard error.

The seven metallic elements namely, magnesium, copper, manganese, ferrous, zinc, nickel and lead analyzed by the atomic absorption spectrophotometer indicated that lead was absent in all the species and magnesium was found in highest concentration, followed by ferrous; nickel was recorded in least concentration (Table 2).
O. foreaui showed highest concentration of copper, manganese, ferrous and zinc (57.65, $539.20,6402$, and $211.20 \mu \mathrm{gmL}^{-1}$, respectively). The concentration of nickel was maximum in $S$. bohneri $\left(11.05 \mu \mathrm{gmL}^{1}\right)$. The highest concentration of magnesium was in $O$. acuminata $\left(21.05 \mathrm{mg} \mathrm{g}^{-1}\right)$ and it was least in $O$. foreaui $\left(12.812 \mathrm{mg} \mathrm{g}^{-1}\right)$. 
Table 2 - Mineral composition* ${ }^{*}$ in $\mu \mathrm{gmL}^{-1}$ ) of seven species of cyanobacteria isolated from different aquatic habitats of the Western Ghats of Karnataka.

\begin{tabular}{|c|c|c|c|c|c|c|c|c|}
\hline Source & Species & $\mathbf{C u}$ & Mn & $\mathbf{F e}$ & $\mathbf{Z n}$ & $\mathbf{N i}$ & Mg & $\mathbf{P b}$ \\
\hline Sulfur spring & $\begin{array}{l}\text { Calothrix } \\
\text { fusca } \\
\text { Gloeocapsa }\end{array}$ & $38.90 \pm 0.8$ & $204.80 \pm 0.6$ & $4779.00 \pm 0.3$ & $94.00 \pm 0.9$ & $13.20 \pm 2.2$ & $13,350.00 \pm 0.0$ & Nil \\
\hline & $\begin{array}{l}\text { livida } \\
\text { Lyngbya }\end{array}$ & $29.00 \pm 3.0$ & $344.40 \pm 0.3$ & $4641.00 \pm 0.8$ & $137.50 \pm 0.4$ & $13.00 \pm 3.2$ & $18,494.00 \pm 0.6$ & Nil \\
\hline & $\begin{array}{l}\text { limnetica } \\
\text { Scytonema }\end{array}$ & $31.20 \pm 2.2$ & $379.60 \pm 0.5$ & $5455.70 \pm 0.2$ & $134.10 \pm 1.1$ & $2.20 \pm 0.7$ & $18,650.00 \pm 0.5$ & Nil \\
\hline Petrochemical & $\begin{array}{l}\text { bohneri } \\
\text { Oscillatoria }\end{array}$ & $42.96 \pm 1.3$ & $211.50 \pm 2.0$ & $3367.00 \pm 1.0$ & $102.60 \pm 2.2$ & $11.05 \pm 0.1$ & $13,190.00 \pm 1.4$ & Nil \\
\hline effluent & acuminata & $15.20 \pm 0.6$ & $161.90 \pm 3.3$ & $3365.00 \pm 3.2$ & $53.00 \pm 0.3$ & $5.40 \pm 0.0$ & $21,050.00 \pm 0.1$ & Nil \\
\hline & calcuttensis & $13.60 \pm 1.5$ & $255.70 \pm 1.0$ & $2237.50 \pm 1.2$ & $80.00 \pm 0.1$ & $5.80 \pm 2.2$ & $18,600.00 \pm 0.1$ & Nil \\
\hline Sewage water & $\begin{array}{l}\text { Oscillatoria } \\
\text { foreaui }\end{array}$ & $57.65 \pm 1.9$ & $539.20 \pm 0.2$ & $6402.00 \pm 0.5$ & $211.20 \pm 0.2$ & $9.37 \pm 1.2$ & $12,812.00 \pm 1.0$ & Nil \\
\hline
\end{tabular}

*Values are the means of three replicates \pm standard error.

\section{DISCUSSION}

\section{Carbohydrate, protein, amino acids and lipids}

The analysis showed that maximum amount of total carbohydrate was found in S. bohneri $(28.4 \%$ dry weight) and minimum in $O$. foreaui ( $8 \%$ of dry weight). The carbohydrates formed a major component of these species, except $O$. calcuttensis in which the total lipid was higher (20\% dry weight). Four species of cyanobacteria from sulfur spring showed high concentration of carbohydrates than others.

The influence of effluents on the biochemical composition of cyanobacteria has been studied by Manoharan and Subramanian (1992). They conducted an experiment to see the influence of paper mill effluent on the physiology and biochemistry of the $O$. pseudogeminata var. unigranulata and found that total carbohydrate content of Oscillatoria of paper mill effluents showed more than two-fold increase in its level from that of the control. But total free amino acid, total protein and total lipid content was less with unsterilized as well as sterilized effluents. Hosmani and Anitha (1998) reported similar type of results for carbohydrate and protein contents of Microcystis aeruginosa, $\left(84.44\right.$ and $22.0 \mathrm{mg} \mathrm{mL}^{-1}$ of carbohydrates and protein, respectively) The investigation carried out by Walach (1987) indicated that carbohydrate synthesis increased with decreased nitrogen availability under constant carbon availability.

Besides food value, extracellular and intracellular carbohydrates of cyanobacteria are involved in some other properties. The cellular carbohydrate content serve to facilitate the buoyancy changes in the bloom forming $M$. aeruginosa reported by Kromkamp and Mur (1984). Another characteristic feature of cyanobacteria is their ability to secrete carbohydrate and protein extracellularly and their potential role in metal removal and in food and package industries (Shah et al., 2000). Kawaguchi and Decho (2000) and Kawaguchi et al. (2003) reported the extracellular polymeric secretion by Schizothrix sp., Synechocystis sp. and Oscillatoria sp. found in the Exuma Cays and Highborne cay in the Bahamas, which contained acidic polysaccharides and proteins. Growth promoting and inhibiting effect of carbohydrates secreted as extracellular substances by some species of cyanobacteria was reported by Safonova and Reisser (2005).

In the present study, the maximum amount of total protein and total free amino acid was found in $O$. foreaui ( $7 \%$ of dry weight). O. calcuttensis showed higher concentration of total lipid (20\% of dry weight). The total percentage of protein was less when compared to other cyanobacterial strains. The four strains of Spirulina were analyzed for their protein and total lipid contents by Fatma et al. (1994) and values obtained were within the range of $43-55 \%$ and $2.7-6.8 \%$, respectively. The protein content was highest and lipid content was lowest when compared to the present study.

Shashikumar and Madhyastha (2002) reported a total of $18.4 \%$ amino acid content in the Synechococcus aquatilis, isolated from an estuary which was very high compared to the values of the present study, whereas Phormidium tenue 
contained 5.24\% of amino acids which agreed with the present study.

Cyanobacteria contain a variety of amino acids and hormonal substances along with sugars and are involved in the improvement of soil texture by acting as chelating agents for heavy metals; they may stimulate the growth of heterotrophic bacteria and also act as growth promoting substances for the plants (Misra and Kaushik, 1989).

The biochemical constituents of cyanobacteria depends on the nature of strains, physiological state of the culture and the environment (Vargas et al., 1998; Subhashini et al., 2003; Maslova et al., 2004; Rosales et al., 2005). Subhashini et al. (2003) observed significant variations in protein content among the four isolates of Anabaena azollae. Authors also stressed about the biochemical variations that enabled to distinguish between the subspecies in several cyanobacterial genera. Rosales et al. (2005) reported about the physiological competence of Synechococcus sp. in hypersaline medium. They observed high cell contents of chlorophyll a, carotenoids, proteins and carbohydrates at $100 \mathrm{ppt}$ and in good nutrient conditions. There are certain factors which also influence the protein synthesis (Borbely et al., 1985; Bhagwat and Apte, 1989). Over 300 nitrogen containing metabolites which are lipopeptide in nature have been reported from marine cyanobacteria (Tan, 2007).

\section{Fatty acids}

With regard to the fatty acid composition, all the species showed high levels of saturated fatty acids with the values ranging from 0.25 to $45.3 \%$, whereas the levels of monounsaturated and polyunsaturated fatty acids (PUFA) were generally low in the present study. Similar results were also obtained by Vargas et al. (1998) and Caudales et al. (2000). Caudales et al. (2000) studied the cellular fatty acids in Dermocarpa, Xenococcus, Dermocarpella, Myxosarcina and Pleurocapsa species which contained high proportion of saturated fatty acids (26-41\% of the total) and unsaturated straight chains $(40-67 \%)$. In the present study, the contents of lauric acid $\left(\mathrm{C}_{12: 0}\right)$ was highest in all the seven species. But some researchers have reported palmitic acid as the most prevalent fatty acid in cyanobacteria (Vargas et al., 1998; Sassaki et al., 2005).

The influence of various environmental factors on the fatty acid composition is also unveiled. For example, Olvera - Ramirez et al. (2000) reported the fatty acid content in Calothrix sp., isolated from a rice field in Mexico, was influenced by the nitrate content in the culture medium and its polyunsaturated fatty acid content was more. The effect of light, temperature and salinity on the lipid and fatty acid composition in some species isolated from different habitats have also been reported by many workers (Rezanka et al., 2003; Maslova et al., 2004; Liu et al., 2005; Rosales et al., 2005). Besides, lipids and fatty acids play an important role in the tolerance of cyanobacterial cells to various environmental stresses such as desiccation, salt induced damage, low temperature, high light induced photoinhibition (Singh et al., 2002).

One of the factors affecting the value of cyanobacteria as a food source is its PUFA content; consequently isolated species from different polluted water bodies and sulfur spring should be only of a limited value. Kumar et al. (2003) showed that polyunsaturated fatty acids varied among the strains. Similar results were obtained in the present study. Matsunaga et al. (1995) reported high cis - palmitoleic acid content (54.5 and $54.4 \%$ of total fatty acid, respectively) in two marine species of Phormidium and Oscillatoria. However, in the present study, polyunsaturated fatty acid content was low and in few others, it was absent. One of the species lacking PUFA was O. limnetica which could be alternatively grown aerobically or anaerobically with sulfide as electron donor as reported by Oren et al. (1985) who observed that Oscillatoria limnetica synthesized monounsaturated fatty acids (MUFA) by desaturation of their saturated counterparts in the presence as well as in the absence of molecular oxygen. But Kumar et al. (2003) and Rezanka et al. (2003) reported higher concentration of PUFA in some strains investigated by them. The fatty acid content of cyanobacteria is also influenced by certain effluents. Manoharan and Subramanian (1993) observed changes in the levels of different fatty acids which were influenced by the effluents. This could be one of the factors that affect the fatty acid composition of cyanobacteria isolated from different habitats which was evidenced in the present study.

Fatty acid composition is used as an effective tool in clarifying the taxonomical problems of cyanobacteria (Kruger et al., 1995; Li and Watanabe, 2004). Kruger et al. (1995) divided Microcystis isolates into subgroups which were 
characterized by a high content of polyunsaturated fatty acids $(27-44 \%)$ and low content of palmitoleate. According to them, the toxic strains and nontoxic strains of Microcystis should be placed in separate groups.

\section{Mineral content}

The cyanobacteria are also rich in minerals as they form an integral part of the cell. In the present study, higher concentration of magnesium was observed in all the species as they formed a key mineral of the chlorophyll molecule. Heavy metals such as copper, ferrous, manganese, nickel, mercury, cadmium, zinc, lead, molybdenum, etc. are the essential micronutrients required for the growth of cyanobacteria and in higher concentration, they may have an inhibitory effect on the growth (Kannan and Subramanian, 1992; Reddy et al., 2002).

Venkataraman and Becker (1985) reported some minerals in different species of Spirulina. There is a wide variation in mineral composition between the species of Spirulina. Similar trend was also noticed among Oscillatoria species in the present study. Subhashini et al. (2003) analysed four micronutrients, namely, copper, manganese, ferrous and zinc in Anabaena species. Of the four isolates of A. azollae, A. azollae - AM recorded maximum copper and manganese content in the concentration of 233 and $1217 \mu \mathrm{gmL}^{-1}$, respectively. A. azollae - $\mathrm{AF}$ recorded maximum ferrous and zinc content in the concentration of 2365 and $900 \mu \mathrm{gmL}^{-1}$, respectively.

Heavy metals are important environmental pollutants. Cations uptake and their toxicity was extensively studied in cyanobacteria by many investigators (Ahluwalia and Kaur 1989; Khare and Bisen 1991; Pandey et al., 1996). Less toxicity of nickel and copper was due to their use as essential elements for various metabolic processes. Mercury was more toxic to the test organisms than nickel and copper. At acidic $\mathrm{pH}$, heavy metals were more toxic to the growth; EDTA was more effective chelator than citrate and glutamine which played a protective role against the metal toxicity. Moffett et al. (1997) reported that cell densities of cyanobacteria declined drastically in harbours subjected to high anthropogenic copper inputs which indicated the copper toxicity at higher concentration.

The ferrous was the second richest mineral component after magnesium in all the species of the present study. Ferrous acts as a cofactor of many enzymes and even its deficiency leads to the loss of biochemical pathway in cyanobacteria. The ability of cyanobacteria to accumulate heavy metals from the polluted water bodies and transform them into nontoxic form has been successfully utilized in bioremediation processes (Samal et al., 2004; Hernandez and Olguin, 2002). The investigation undertaken by Saxena and Kumar (2004) on the effect of mercuric chloride on testicular phosphatases and to evaluate the modulatory potential of $S$. fusiformis on mercury induced testicular toxicity in Swiss albino mice revealed that the cotreatment of Spirulina with mercuric chloride effectively reduced the mercuryinduced testicular changes.

\section{ACKNOWLEDGEMENTS}

The authors thank the Chairman and the staff of the Department of Biosciences, Mangalore University for their kind help during the period of investigation. We also thank Dr. Shameena Aziz and Dr. Sugatha of Central Plantation Crop Research Institute, Kasaragod for their assistance in the analysis of fatty acid and mineral content.

\section{REFERENCES}

Ahluwalia, A. S. and Kaur, M. (1989), Nickel toxicity on growth and heterocyst formation in a nitrogen fixing blue green alga. Phykos, 28: 196 - 200.

Anupama, P. R. (2000), Value added food: single cell protein. Biotechnol. Advan., 18: 459-479.

Anusuya, D. M.; Subbulakshmi, G.; Madhavi, D. M. and Venkataraman, L. V. (1981), Studies on the proteins of mass cultivated blue green alga (Spirulina platensis). J. Agri. Food Chem., 29: 522 - 525.

Bhagwat, A. A. and Apte, S. K. (1989), Comparative analysis of protein induced by heat shock, salinity and osmotic stress in the nitrogen fixing cyanobacterium, Anabaena sp. strain L - 31. J. Bacteriol., 171: 5187 - 5189.

Borbely, G.; Suranyi, G.; Korcz, A. and Palfi, Z. (1985), Effect of heat shock on protein synthesis in the cyanobacterium Synechococcus sp. strain PCC 6301. J. Bacteriol., 161: 1125 - 1130.

Borowitzka, M. A. (1988), Vitamins and fine chemicals from microalgae. In: Borowitzka, M. A. and Borowitzka, L. J. (Ed.). Microalgal Biotechnology, p. $153-196$. 
Cardozo, K. H. M.; Guaratini, T.; Barros, M. P.; Falcao, V. R.; Tonon, A. P.; Lopes, N. P.; Campos, S.; Torres, M. A.; Souza, A. O.; Colepicolo, P. and Pinto, E. (2007), Metabolites from algae with economical impact. Com. Biochem. Physiol., 146: $60-78$.

Caudales, R.; Wells, J. M. and Butterfield, J. E. (2000), Cellular fatty acid composition of cyanobacteria assigned to subsection II, order Pleurocapsales. Internat. J. Syst. Evolut. Microbiol., 50: 1029 - 1034.

Ciferri, O. and Tiboni, O. (1985), The biochemistry and industrial potentials of Spirulina. Annu. Rev. Microbiol., 39: 503 - 526.

Dubois, M.; Gilles, K. A.; Hamilton, J. K.; Rebers, P. A. and Smith F. (1956), Colorimetric method for determination of sugars and related substances. Anal. Chem., 28: 350 - 356.

Fatma, T.; Sarada, R. and Venkataraman, L. V. (1994), Evaluation of selected strains of Spirulina for their constituents. Phykos, 33: $89-97$.

Ferris, M. J. and Hirsch, C. F. (1991), Method for isolation and purification of cyanobacteria. Appl. Environ. Microbiol., 57: 1448 - 1452.

Folch, J.; Lees, M. and Stanley, G. H. S. (1957), A simple method for the isolation and purification of total lipids from animal tissues. J. Biol. Chem., 226: $497-509$.

Hernandez, E. and Olguin, E. J. (2002), Biosorption of heavy metals influenced by the chemical composition of Spirulina sp. (Arthrospira) biomass. Environ. Tech., 23: 1369 - 1377.

Hosmani, S. P. and Anita, M. C. (1998), Biochemical study of Microcystis aeruginosa Kutz. Ecol. Environ. Conser., 4: 255 - 257.

Jensen, G. S. and Ginsberg, D. I. (2000), Consumption of Aphanizomenon flos- aquae has rapid effects on the circulation and function of immune cells in humans. JAMA, 2: $50-58$.

Kannan, V. and Subramanian, D. (1992), Effect of removal of molybdenum in two cyanobacteria Tolypothrix tenuis (Kutz) Schmidt em. and Mastigocladus laminosus Cohn. Indian J. Microbiol., 32:185 - 187.

Karna, R. R.; Uma, L.; Subramanian, G. and Mohan, P. M. (1999), Biosorption of toxic metal ions by alkali extracted biomass of a marine cyanobacterium Phormidium valderianum BDU 30501. World J. Microbiol. Biotechnol., 15: 729 - 732.

Kawaguchi, T.; Sayegh, H. A. and Decho, A. W. (2003), Development of an indirect competitive enzyme linked immunosorbent assay to detect extracellular polymeric substances (EPS) secreted by the marine stromatolite forming cyanobacteria, Schizothrix sp. J. Immunoassay Immunochem., 24: 29 -39 .
Kawaguchi, T. and Decho, A. W. (2000), Biochemical characterization of cyanobacterial extracellular polymers (EPS) from modern marine stromatolites (Bahamas). Prep. Biochem. Biotechnol., 30: 321 330.

Khare, P. and Bisen, P. S. (1991), Mitigating effect of physico - chemical factors on $\mathrm{Ni}^{2+} \mathrm{Hg}^{2+}$ and $\mathrm{Cu}^{2+}$ toxicity in Cylindrospermum IU 942. Environ. Technol., 12: 297 - 301.

Kromkamp, J. C. and Mur, L. R. (1984), Buoyant density changes in the cyanobacterium Microcystis aeruginosa due to changes in the cellular carbohydrate content. FEMS Microbiol. Lett., 25: 105 $-109$.

Kruger, G. H. J.; De Wet, H.; Kock, J. L. F. and Pieterse, A. J. H. (1995), Fatty acid composition as a taxonomic characteristic for Microcystis and other coccoid cyanobacteria (blue green alga) isolates. Hydrobiologia, 308: 145 - 151.

Kumar, K.; Lakshmanan, A. and Kannaiyan, S. (2003), Bioregulatory and therapeutic effects of blue green algae. Indian J. Microbiol., 43: 9 - 16.

Li, R. and Watanabe, M. (2004), Fatty acid composition of planktonic species of Anabaena (cyanobacteria) with coiled trichomes exhibited a significant taxonomic value. Curr. Microbiol., 49: $376-380$.

Liu, X. J.; Jiang, Y. and Chen, F. (2005), Fatty acid profile of the edible filamentous cyanobacterium Nostoc flagelliforme at different temperatures and developmental stages in liquid suspension culture. Process Biochem., 40: 371 - 377.

Lowry, O. H.; Rosenbrough, N. J.; Farr, A. L. and Randall, R. J. (1951), Protein measurement with the Folin - phenol reagent. J. Biol. Chem., 193: 265 275.

Mahajan, G. and Kamat, M. (1995), Gamma linolenic acid production from Spirulina platensis. Appl. Microbiol. Biotechnol., 43: 466 - 469.

Manoharan, C. and Subramanian, G. (1992), Interaction between paper mill effluentss and the cyanobacterium Oscillatoria pseudogeminata var. unigranulata. Poll. Res., 11: $73-84$.

Manoharan, C. and Subramanian, G. (1993), Influence of effluents on fatty acid content of a cyanobacterium. Curr. Sci., 65: 353 - 355.

Maslova, I. P.; Mouradyan, E. A.; Lapina, S. S.; Klyachko-Gurvich, G. L. and Los, D. A. (2004), Lipid fatty acid composition and thermophilicity of cyanobacteria. Russian J. Plant Physiol., 51: 353 360.

Matsunaga, T.; Takeyama, H.; Miura, Y.; Yamazaki, T.; Furuya, H. and Sode, K. (1995), Screening of marine cyanobacteria for high palmitoleic acid production. FEMS Microbiol. Lett., 133: 137 - 141. 
Miller, L. and Berger, T. (1985), Bacteria identification by gas chromatography of whole cell fatty acids. Hewlett - Packard Application Note. 228 - 241. Hewlett - Packard, Avondale, Pennsylvania, 8p.

Misra, S. and Kaushik, B. D. (1989), Growth promoting substances of cyanobacteria. II. Detection of amino acids, sugars and auxins. Proc. Indian Natn. Sci. Acad., B 55: 499 - 504.

Moffett, J. W.; Brand, L. E.; Croot, P. L. and Barbeau, K. A. (1997), $\mathrm{Cu}$ speciation and cyanobacterial distribution in harbours subjected to anthropogenic $\mathrm{Cu}$ inputs. Limnol. Oceanogr., 42: 789 - 799.

Moore, S. and Stein, W. H. (1948), Photometric ninhydrin method for use in the chromatography of amino acids. J. Biol. Chem., 176: 367 - 388.

Olvera - Ramirez, R.; Coria - Cedillo, M.; Canizares Villanueva, R. O.; Martinez - Jeronimo, F.; Ponce Noyola, T. and Rios - Leal, E. (2000), Growth evaluation and bioproducts characterization of Calothrix sp. Bioresource Technol., 72: 121 - 124.

Oren, A.; Fattom, A.; Padan, E. and Tietz, A. (1985), Unsaturated fatty acid composition and biosynthesis in Oscillatoria limnetica and other cyanobacteria. Arch. Microbiol. 141: 138 - 142.

Pandey, P. K.; Singh, B. B.; Mishra, R. and Bisen, P. S. (1996), $\mathrm{Ca}^{2+}$ uptake and its regulation in the cyanobacterium Nostoc MAC. Curr. Microbiol., 32: $332-335$.

Poppitti, J. A. and Sellers, C. (1994), Practical Techniques for Laboratory Analysis. CRC Press. 188 pp.

Rastogi, R. P. and Sinha, R. P. (2009), Biotechnological and industrial significance of cyanobacterial secondary metabolites. Biotechnol. Adv., 27: 521 539.

Reddy, M. N.; Srivastava, V. and Patil, V. (2002), Effect of cadmium, lead and zinc on growth of some cyanobacteria. J. Ecobiol., 14: 161 - 167.

Rezanka, T.; Viden, I.; Go, J. V.; Dor, I. and Dembitsky, V. M. (2003), Polar lipids and fatty acids of three wild cyanobacterial strains of the genus Chroococcidiopsis. Folia Microbiol. 48: 781 - 786.

Rosales, N.; Ortega, J.; Mora, R. and Morales, E. (2005), Influence of salinity on the growth and biochemical composition of the cyanobacterium Synechococcus sp. Ciencias Marinas, 31: 349 - 355.

Safonova, E. and Reisser, W. (2005), Growth promoting and inhibiting effects of extracellular substances of soil microalgae and cyanobacteria on Escherichia coli and Micrococcus luteus. Phycol. Res., 53: 189 - 193.

Samal, A. C.; Bhar, G. and Santra, S. C. (2004), Biological process of arsenic removal using selected microalgae. Indian J. Exp. Biol. 42: 522 - 528.

Sassaki, G. L.; Gorin, P. A. J.; Reis, R. A.; Serrato, R. V.; Elifio, S. L. and Iacomini, M. (2005), Carbohydrate, glycolipid and lipid components from the photobiont (Scytonema sp.) of the lichen, Dictyomema glabratum. Carbohydr. Res., 340: 1808 $-1817$.

Saxena, P. S. and Kumar, M. (2004), Modulatory potential of Spirulina fusiformis on testicular phosphatases in Swiss albino mice against mercury intoxication. Indian J. Exp. Biol., 42: 998 - 1002.

Saxena, R. K.; Raghuvanshi, R.; Singh, S. and Bisen, P. S. (2006), Iron induced metabolic changes in the diazotrophic cyanobacterium Anabaena PCC7120. Indian J. Exp. Biol., 44: 849 - 851.

Shah, V.; Ray, A.; Garg, N. and Madamwar, D. (2000), Characterization of the extracellular polysaccharides produced by the marine cyanobacterium Cyanothece ATCC 51142 and its exploitation toward metal removal from solutions. Curr. Microbiol., 40: $274-$ 278.

Shashikumar, K. C. and Madhyastha, M. N. (2002), Amino acid profile of Synechocystis aquatilis isolated from an estuary near Mangalore coast. Indian $J$. Microbiol., 42: 81 - 82 .

Singh, S. C.; Sinha, R. P. and Hader, D. P. (2002), Role of lipids and fatty acids in stress tolerance in cyanobacteria. Acta Protozool., 41: 297 - 308.

Stanier, R.Y.; Kunisawa, R.; Mandel, M. and Cohen Bazire, G. (1971), Purification and properties of unicellular blue green algae (order Chroococcales). Bacteriol. Rev., 35: 171 - 205.

Subhashini, R.; Kumar, K. and Kannaiyan, S. (2003), Intrinsic antibiotic resistance and biochemical characteristics of Anabaena azollae isolated from Azolla - cultures. Indian J. Microbiol., 43; 165 -169.

Tan, L. T. (2007), Bioactive natural products from marine cyanobacteria for drug discovery. Phytochem., 68: $954-979$.

Thajuddin, N. and Subramanian, G. (2005), Cyanobacterial biodiversity and potential applications in biotechnology. Curr. Sci., 89: 47 - 57.

Vargas, M. A.; Rodriguez, H.; Moreno, J.; Olivares, H.; Del Campo, J. A.; Rivas, J. and Guerrero, M. G. (1998), Biochemical composition and fatty acid content of filamentous nitrogen fixing cyanobacteria. J. Phycol., 34: 812 - 817.

Venkataraman, L. V. and Becker, E. W. (1985), Biotechnology and Utilization of Algae - The Indian Experience. Dept. Sci. Technol. New Delhi, India and CFTRI, Mysore, India. 257 pp.

Walach, M. R.; Bazin, M. and Pirt, J. (1987), Computer control of carbon - nitrogen ratio in Spirulina platensis. Biotechnol. Bioeng., 29: 520 - 528.

Received: May 03, 2010; Revised: May 27, 2011; Accepted: August 09, 2011. 


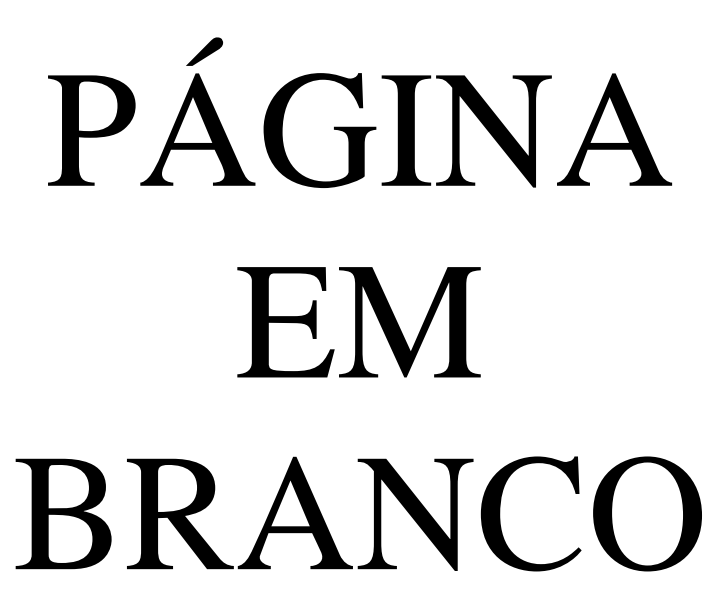

